
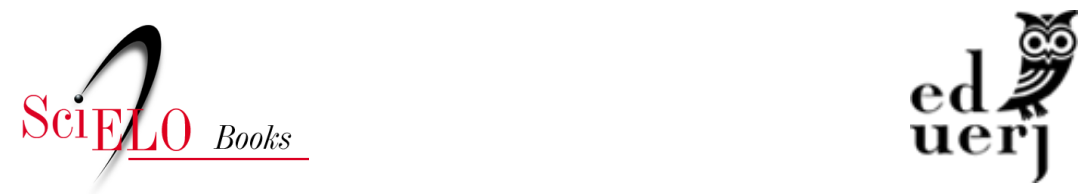

\title{
A produção imobiliária do PMCMV no bairro de Santa Cruz - Rio de Janeiro/RJ: Análises e contextos no período de 2005 e 2010
}

\author{
Vania Regina Jorge da Silva \\ Miguel Angelo Ribeiro
}

\section{SciELO Books / SciELO Livros / SciELO Libros}

SILVA, V. R. J., and RIBEIRO, M. A. A produção imobiliária do PMCMV no bairro de Santa Cruz - Rio de Janeiro/RJ: Análises e contextos no período de 2005 e 2010. In.: MAIA, D. S., and MARAFON, G. J., eds. O programa Minha Casa Minha Vida: habitação e produção do espaço urbano em diferentes escalas e perspectivas [online]. Rio de Janeiro: EDUERJ, 2020, pp. 215-243. ISBN: 978-6500-03029-7. https://doi.org/10.7476/9786500030297.0009.

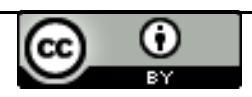

All the contents of this work, except where otherwise noted, is licensed under a Creative Commons Attribution 4.0 International license.

Todo o conteúdo deste trabalho, exceto quando houver ressalva, é publicado sob a licença Creative Commons Atribição 4.0.

Todo el contenido de esta obra, excepto donde se indique lo contrario, está bajo licencia de la licencia Creative Commons Reconocimento 4.0. 


\title{
A produção imobiliária do PMCMV no bairro de Santa Cruz - Rio de Janeiro/RJ: Análises e contextos no período de 2005 e $2010^{1}$
}

\author{
Vania Regina Jorge da Silva \\ UERJ (FEBF) - Professora Adjunta \\ Miguel Angelo Ribeiro \\ UERJ - IGEOG - PPGEO - Professor Associado
}

[...] Podemos afirmar que habitar uma cidade não se resume apenas a morar em uma casa ou apartamento, por mais confortável e adequado que este provavelmente seja ou deveria ser. Habitar não é apenas possuir uma residência física [...]. O habitar e o construir, embora sejam experiências distintas, configuram o movimento de instauração do ser-no-mundo (Barbosa, p. 426, 2017).

\section{Introdução}

O presente artigo sobre a produção imobiliária do Programa Minha Casa Minha Vida (PMCMV) no bairro² de Santa Cruz, localizado na Zona

${ }^{1}$ O presente artigo faz parte da tese de Vânia Regina Jorge da Silva, defendida em janeiro de 2016 no Programa de Pós-Graduação em Geografia (PPGEO) do Instituto de Geografia (IGEOG) da Universidade do Estado do Rio de Janeiro (UERJ), intitulada O bairro de Santa Cruz-RJ no contexto da metropolização: escalas, dinâmicas e processos socioespaciais - 2005-15, sob orientação do professor Miguel Angelo Ribeiro. $\mathrm{O}$ artigo que apresentamos trata-se de uma versão para o presente livro.

2 Na nossa pesquisa, nos referimos ao bairro como sendo a menor porçáo delimitada e reconhecida pela divisão político-administrativa do município do Rio de Janeiro. 
Oeste da urbe carioca, tem por preocupação observar as mudanças espaciais no referido bairro, relacionadas a uma gama de investimentos. ${ }^{3}$

Em um contexto geral, o número de domicílios urbanos cresceu de 2 milhóes para aproximadamente 40 milhóes em meio século de urbanização acelerada. Tal fato, como apontou Barbosa (2017, p. 429), acompanhou o crescimento da população em geral e da urbana em particular.

Entretanto, apenas 20,0\% dessas moradias fizeram parte direta da construção e do financiamento por parte dos governos (federal, estaduais e municipais) e de suas agências de fomento. Grande parte da populaçáo urbana construiu suas residências com seus próprios recursos e esforços, diante da insuficiência das políticas estatais de habitação e do desinteresse do mercado formal pelas demandas das "populaçóes de baixa renda".

Desta feita, relacionamos essas mudanças a processos tanto de metropolização como o de expansão urbana no período que se estende dos anos de 2005 até 2015. Este recorte temporal justifica-se em decorrência dos incrementos em investimentos imobiliários terem a sua projeção e implementaçáo nessa faixa de tempo, ocasionando mudanças no bairro, entre outras, a produção intensificada no setor imobiliário.

Nesse contexto, houve uma promoção não só uma quantidade expressiva de empreendimentos no bairro de Santa Cruz, com destaque para o PMCMV. ${ }^{4}$ Como aponta Barbosa (2017), o Programa Minha Casa Minha

3 Sobre empreendimentos mencionados, bem como a relação estabelecida entre eles e o processo de metropolização, consultar: O bairro de Santa Cruz-RJ no contexto da metropolização: escalas, dinâmicas e processos socioespaciais - 2005-15. Disponível em: http://catalogo-redesirius.uerj.br/sophia_web/.

4 Com o objetivo de diminuir o déficit habitacional, estimular o crescimento da economia brasileira, manter o desenvolvimento dos setores imobiliários e da construçáo civil, o Governo Federal criou, em julho de 2009, o Programa Minha Casa /Minha Vida (PMCMV). Esse está vinculado ao Programa de Aceleração do Crescimento (PAC). Incentiva a produção e aquisição de novas unidades habitacionais para as famílias com renda na faixa de 0 a 10 salários mínimos com a captação de recursos do Fundo de Garantia por Tempo de Serviço (FGTS) e do Sistema Brasileiro de Poupanças e Empréstimos (SBPE). No Programa Minha Casa Minha Vida, o Governo Federal, em conjunto com a Caixa Econômica Federal, estabeleceu três faixas de financiamento dos imóveis a serem construídos, contemplando as famílias que possuem renda entre 0 e 10 salários mínimos. A primeira faixa atenderia às famílias com renda de 0 a 3 salários mínimos, a segunda, contemplaria as que possuem renda de 3 a 6 salários 
Vida vem no contexto da criação do Ministério das Cidades, no governo do presidente Luiz Inácio Lula da Silva, no qual "a moradia de baixa renda" na agenda das políticas governamentais de habitação obteve destaque, com políticas anteriormente abandonadas, exemplificadas com a extinção por decreto do banco Nacional de Habitação em 1986 e a crise do sistema financeiro de habitação.

Para Barbosa (2017, pp. 431-32),

o Programa Minha Casa Minha Vida (PMCMV) é o exemplo maior da retomada do enfrentamento do déficit de moradia para a 'populaçáo de baixa renda', incluindo a substituição de 'assentamentos precários ou de risco' (favelas, cortiços, loteamentos clandestinos) por 'moradias adequadas', por parte do estado.

Reconhecemos que tal Programa significou a possibilidade que a camada da população de menor renda pudesse se inserir no mercado formal com o tipo de moradia em condomínios fechados acompanhados de área de lazer. Para tal, articulando com o que Silva (1996) observou sobre a construçáo de elementos simbólicos na inovação do tipo de moradia em condomínios fechados, um novo conceito de morar, temos de perceber o que ocorre no bairro de Santa Cruz para além do pensamento reducionista de que o propósito era tão somente o deslocamento da população mais pobre para áreas mais distantes do centro metropolitano do Rio de Janeiro.

O recorte espacial escolhido, o bairro de Santa Cruz (figura 1), se deve a vários motivos, entre eles o interesse dos autores em analisar processos espaciais na parte Oeste do município do Rio de Janeiro, localizada ao norte do Maciço da Pedra Branca, área contemplada pelo Programa, influenciando na expansão da Metrópole a partir do capital imobiliário e do mercado de terras, sob a influência do Estado.

Nesse contexto, esse artigo tem como objetivos apreender e analisar o processo de expansão do setor imobiliário ao compararmos o bairro de Santa Cruz com outros na cidade do Rio de Janeiro durante o período que compre-

mínimos e, por último, as de 6 a 10 salários mínimos. As famílias com renda de 0 a 3 salários mínimos que seráo contempladas pelo Programa são indicadas e selecionadas pela administraçáo municipal ou pelo Governo do Estado e, no caso de Brasília, pelo Governo do Distrito Federal. 
ende os anos de 2005 e 2015. Entre as questóes norteadoras temos, no que diz respeito à construção de moradias, por exemplo: como Santa Cruz se destaca no contexto da urbe carioca? Ainda a respeito da promoção de unidades imobiliárias do PMCMV em Santa Cruz, estamos observando tão somente a ratificação do bairro como lócus para a reprodução da classe menos abastada?

Nas palavras do senso comum, é a repetição de uma noção em que o pobre deve ser levado a morar longe dos centros principais e, portanto, em áreas com menor quantidade de equipamentos urbanos de uso coletivo ratificando a cidade dual centro-periferia?

Para alcançarmos os objetivos e respondermos aos questionamentos propostos, buscamos dados disponíveis em relatórios da Secretaria Municipal de Urbanismo do Rio de Janeiro (SMU) para compreender as diferenças e similaridades da produção imobiliária no bairro de Santa Cruz em comparaçáo a outros na cidade carioca. Ainda, cabe ressaltar que esse tipo de empreendimento, embora seja intitulado como produçáo social de moradia, opera de acordo com a lógica de produção para o mercado. Essa discussão está de acordo com Pereira (2005), Lencioni (2008), Brenner (2014), entre outros autores citados no decorrer do texto. 
Figura 1 - O bairro de Santa Cruz-RJ em contextos escalares

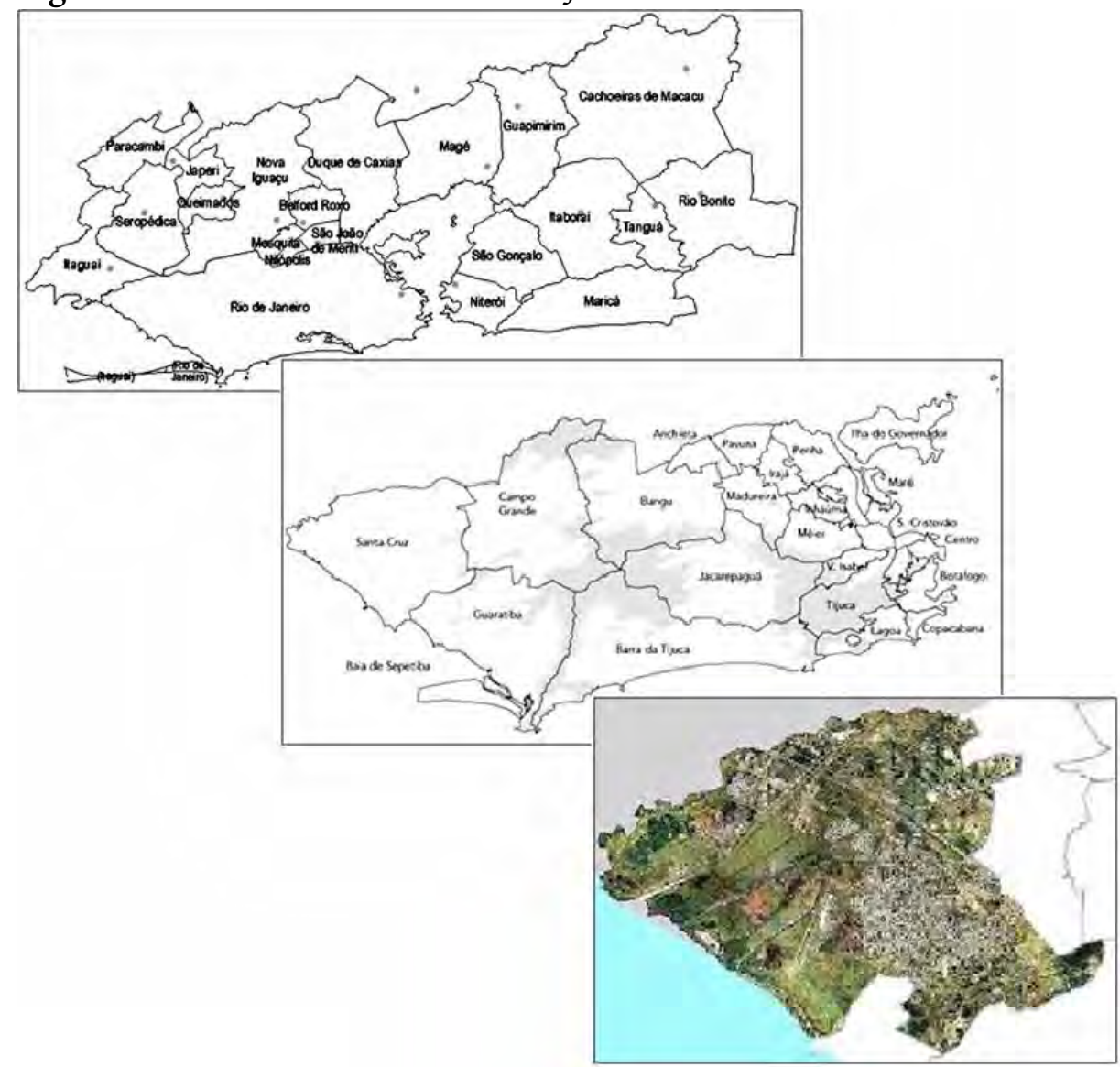

Fonte: Armazém de dados da Prefeitura do Rio de Janeiro. Elaborado por Vânia Silva (2015).

O artigo está dividido em duas seçôes: a primeira relaciona a produção imobiliária na urbe carioca, inclusive no recorte espacial de análise, em sua conjuntura político-econômica nacional e global para que possamos compreender o expressivo quantitativo de construçóes do PMCMV no referido bairro. A segunda parte apresenta, com base em relatórios da Secretaria $\mathrm{Mu}$ nicipal de Urbanismo do Rio de Janeiro (SMU), os números relativos à gama de licenciamentos imobiliários no referido recorte temporal selecionado, suscitando novos questionamentos. 


\section{A produção imobiliária no bairro de Santa Cruz- Rio de Janeiro/RJ: PMCMV, reproduçáo da pobreza?}

Segundo os relatórios da SMU do Rio de Janeiro, a partir de 2005 até 2015 percebemos uma intensificação da produção imobiliária em todo o município. Porém, com o objetivo de perceber o que isso significou para o bairro de Santa Cruz em relaçáo ao processo de produção desse setor da economia, cabe observarmos em que aquele momento se diferenciou de momentos anteriores. Primeiramente, no que diz respeito à dinâmica imobiliária apresentada no referido período, Brenner (2014) ressalta a iniciativa de governos em criar condiçóes propícias para o investimento de capitais transnacionais se refletindo no ambiente urbano com estratégias que visam tanto o núcleo metropolitano como as estruturas organizacionais que promovem a expansão com uma urbanização estendida em formas variadas. Então, podemos entender o que vinha acontecendo no município do Rio de Janeiro com investimentos em infraestrutura de transporte público, ${ }^{5}$ o Projeto Porto Maravilha e os investimentos imobiliários, tendo o urbano como meio para a ampliação da acumulação.

Nessa mesma direção, Lencioni (2008) nos aponta que um dos fatores que contribuem para a dispersão da metrópole como uma mancha urbana é o mercado de terras que incorpora áreas menos valorizadas em relação às tradicionais. O que podemos observar em relação ao bairro de Santa Cruz é que, mesmo sendo uma área interna do núcleo metropolitano, há a disponibilidade de terrenos amplos e acessíveis que apresentam esse recorte como área propícia para a expansão urbana. Então, entendemos a produção imobiliária atual no referido bairro com ênfase nos empreendimentos do PMCMV como uma forma de reprodução do capital via urbano que ocorre na direção oeste da urbe carioca, configurando-se como uma expansão urbana via setor imobiliário.

Dessa forma, Sánchez (1998) apresenta o espaço funcional metropolitano relacionado ao assentamento produtivo de indústrias, de serviços e

\footnotetext{
5 Esses empreendimentos de transporte público se referem às instalaçóes de vias expressas com BRS (Bus Rapid System), bem como as linhas de BRTs (Bus Rapid Transit) e o Veículo Leve sobre Trilhos (VLT). Todos estavam relacionados a uma agenda na qual o governo local promovia tais empreendimentos para a locação de capitais transnacionais disponíveis para investimentos deste tipo.
} 
residencial articulado por redes de transporte. Silva (2016) atenta para o fato de que não se pode desperceber que a "divisão e a hierarquização estão na essência do sistema capitalista” (p. 74) em congruência com a especulação imobiliária diferenciando parcelas do solo urbano como meio para auferir maiores lucros. Relacionando Sánchez (1998) e Lencioni (2008), podemos acrescentar que essa dinâmica ocorre tanto na expansão da metrópole como para além dela, a exemplo do espaço intrametropolitano, com uma expansão do adensamento nas áreas internas da cidade.

Nessa direção, temos as observaçôes de Ferreira (2014) que, para entender a produção do espaço em sua materialização dentro da lógica metropolitana, nos valemos do trinômio da homogeneização, fragmentação, hierarquização como um método de análise em que o primeiro termo viabiliza a conformação da cotidianidade do espaço à própria intercambialidade dos lugares. O segundo termo, a fragmentação, viabiliza a intensa mercadificação do solo em que a especulação é utilizada de acordo com os fragmentos diferenciados, promovendo a ampliação dos rendimentos. Essa fragmentação é feita de maneira atrelada ao terceiro termo, o da hierarquização, que promove os diferentes valores de troca em decorrência dos investimentos particularizados, colaborando para reproduzir e ratificar antigas hierarquizaçóes.

No nosso entendimento, essa é uma lógica que alcança lucros em todos os contextos, valendo-se, inclusive, da diferenciação existente, porque as empresas se aproveitam delas e adotam estratégias também distintas de acordo com essas diferenças. Por exemplo, o uso de terrenos amplos, mais acessíveis e afastados dos centros principais da cidade, é oportuno e questionado para a produção, visando camadas da população com menor renda, aproveitando investimentos de recursos públicos, produzindo em grande escala para minimizar os custos e ampliar os lucros.

Para entendermos a lógica do mercado imobiliário para os extratos de renda mais baixos, tivemos de comparar o momento anterior ao recorte temporal selecionado. No período entre 1960-80, na área que compreende desde Deodoro até Sepetiba e Guaratiba, incluindo Santa Cruz, observamos a produção imobiliária para a reprodução prioritária da força de trabalho no contexto urbano-industrial, com os loteamentos irregulares e clandestinos. Nesse contento, a construção de habitação era feita pelos próprios moradores nos finais de semana e com a ajuda da família e dos amigos. Esse padrão tradicional de urbanização, com expansão horizontal pela produção de moradia 
na periferia, predominou até por volta da década de 1980. Desse modo, essa urbanização tradicional apesar de precária e pobre, servia ao capital, mas, sobretudo, ao trabalhador, visto que a "cidade crescia para servir de lócus privilegiado da reprodução do trabalho" (Pereira, 2005, p.160). Em contrapartida, principalmente de 2009 até julho de 2015, tivemos um total de empreendimentos do PMCMV para a cidade do Rio de Janeiro na ordem 35.121 unidades. Sendo que cerca de 50,0\% estáo localizados em Santa Cruz e a ênfase na produção para a faixa de renda mais baixa. Podemos pensar que essa é uma estratégia para direcionar os mais pobres para bem longe das áreas mais seletivas da cidade carioca, porém, afirmamos que esse é um modo de pensar reducionista que não considera diversos elementos que estão envolvidos, para dar sentido a esta realidade.

Como nos indica Pereira (2005), observamos uma dinâmica imobiliária na qual há a emergência de produtos imobiliários condominiais somados à produção pública de habitação social para o mercado. Desse modo, "a cidade muda para servir prioritariamente ao capital” (Pereira, 2005, p. 160). Essas mudanças, inclusive na produçáo imobiliária visando as camadas de menor renda, são denotadas nos grupos envolvidos, nos investimentos e na maneira de se construir e comercializar os produtos imobiliários.

Observamos, no nosso recorte de estudo, pequenas e grandes empresas imobiliárias recorrendo aos fundos disponíveis pelo PMCMV com diversas estratégias, de acordo com a sua capacidade de produção. $\mathrm{O}$ que podemos depreender é que, para os empreendimentos destinados a famílias que ganham entre 0 e 3 SM, a Prefeitura do Rio de Janeiro é o principal agente, junto à Caixa Econômica Federal (CEF), para a venda das unidades às famílias que serão contempladas com subsídio do Governo Federal. Considerando as famílias da faixa 2, que ganham entre 3 e 6 SM, ou da faixa 3, entre 6 e 10 SM, a Prefeitura do Rio de Janeiro age como fiscalizadora diante da legislação de urbanismo, deixando as empresas privadas livres para agirem junto à Caixa Econômica Federal na venda das unidades de habitação para o mercado. $\mathrm{Ou}$ seja, os recursos são do PMCMV e o empreendimento é escolhido pela CEF, só que, as unidades são vendidas pelo e para o mercado imobiliário.

Não podemos deixar de perceber e ignorar como o setor financeiro está envolvido na produção imobiliária em geral e na habitação social em particular. Como destaca Lencioni (2014), a lógica do capital financeiro acompanhada da metropolização é hegemônica, mas possui ritmos e intensidades 
diferentes, por isso, o espaço assim produzido é homogêneo e fragmentado. Segundo a autora, as mudanças na produção do espaço coincidem com o avanço das políticas neoliberais, com as inovaçôes no planejamento, na gestão e na implementação de políticas urbanas imobiliárias e habitacionais em que o neoliberalismo, apesar do discurso contra o Estado, se impóe com a sua proteção, uma urbanização neoliberal que afirma o poder da finança. $\mathrm{O}$ conteúdo expresso é a produção do valor, a apropriação do valor na forma de patrimônio com a generalizaçáo da propriedade condominial. Essa última característica sendo representativa também na produção imobiliária para a população de menor renda.

Nessa mesma direçáo, Pereira (2014) ressalta a ideia de que a construção civil é um setor estratégico, tendo nas relaçóes de trabalho uma das estratégias que lhe permite a produção de excesso de valor e a possibilidade de ampliação do excedente. Outra estratégia é a especulação que aumenta a apropriação da renda da terra. Ambas são importantes para os intentos de sobrevida do sistema capitalista.

Se apropriando do pensamento de Smith (2007) quanto ao conceito de fronteira do capital, Pereira (2014) entende a ideia de fronteira urbana como o fenômeno da urbanizaçáo capitalista na qual observamos novas necessidades e carências da ordem próxima com o emprego de demandas globais para o investimento de capital disponível tendo como essência, o imobiliário e o financeiro. Como novas necessidades da ordem próxima, observamos a produção dos empreendimentos do PMCMV como uma apropriação da ideia de condomínios fechados no qual há a proposta de isolamento em relação ao entorno por muros e guarita, visando uma suposta segurança. Destacamos, novamente, os condomínios, principalmente verticais, que "[...] multiplica e eleva a parte da renda no valor imobiliário e, assim, aumenta a capitalizaçáo da propriedade da terra" (Pereira, 2005, p. 162). São novos conteúdos que se revelam pelas mudanças nas condiçóes de geração de valor, repartição na produção, comercializaçáo e financiamento dos produtos imobiliários. Novas formas de acesso e conceito de propriedade por meio do qual se exacerba os rendimentos do valor, visto que a verticalizaçáo promove a possibilidade de multiplicação da extração da renda da terra.

Nesse contexto, devemos nos remeter a Silva (1996) quando observa a construção de elementos simbólicos para atrair consumidores para o Recreio e para a Barra da Tijuca, locais que na época eram balneários distantes das 
áreas mais proeminentes da cidade. Lançava-se um novo conceito de morar que, embora longe da área central e com difícil acesso, o comprador estaria adquirindo um modo de viver longe dos congestionamentos adensados, com todas as benesses de lazer incluídas. Era a introdução da ênfase na construção de condomínios exclusivos que recebem hoje uma nova onda de produção, visando também classes média-baixa e baixa. Ou seja, é o envolvimento do simbólico para a produção de habitação, mas que, na verdade, promove a possibilidade de grandes ganhos.

A construção de conjuntos habitacionais MCMV tem como particularidade, em relação aos conjuntos de habitação social construídos em períodos anteriores - como os do BNH (Banco Nacional de Habitação) e da antiga COHAB (Companhia de Habitaçáo Popular do Estado do Guanabara), hoje denominada CEHAB (Companhia Estadual de Habitação do Rio de Janeiro) -, o fato de apresentarem a forma de condomínio murado, fechado, com segurança e acesso a equipamentos de lazer exclusivos para os condôminos, caracterizando um tipo particular de segregaçáo, pois isola esse tipo de moradia do restante do bairro pelos extensos muros, como pode ser visto nas fotos 1 e 2 .

$\mathrm{Na}$ primeira foto temos o empreendimento Village Ventura na Av. Padre Guilherme de Decaminada, perto da Av. Brasil. Esse empreendimento na verdade não é um só, são vários, um ao lado do outro. Possui um total de 1500 unidades destinadas a pessoas com renda entre 3 e 6 SM, oferecendo áreas de lazer com piscina, murado e com guarita. Na segunda foto é possível perceber o entorno do empreendimento, caracterizado por uma ocupação anterior sem muito ordenamento, ilegal ou irregular. 


\section{Foto 1 - Empreendimento Village Ventura - Santa Cruz-RJ}

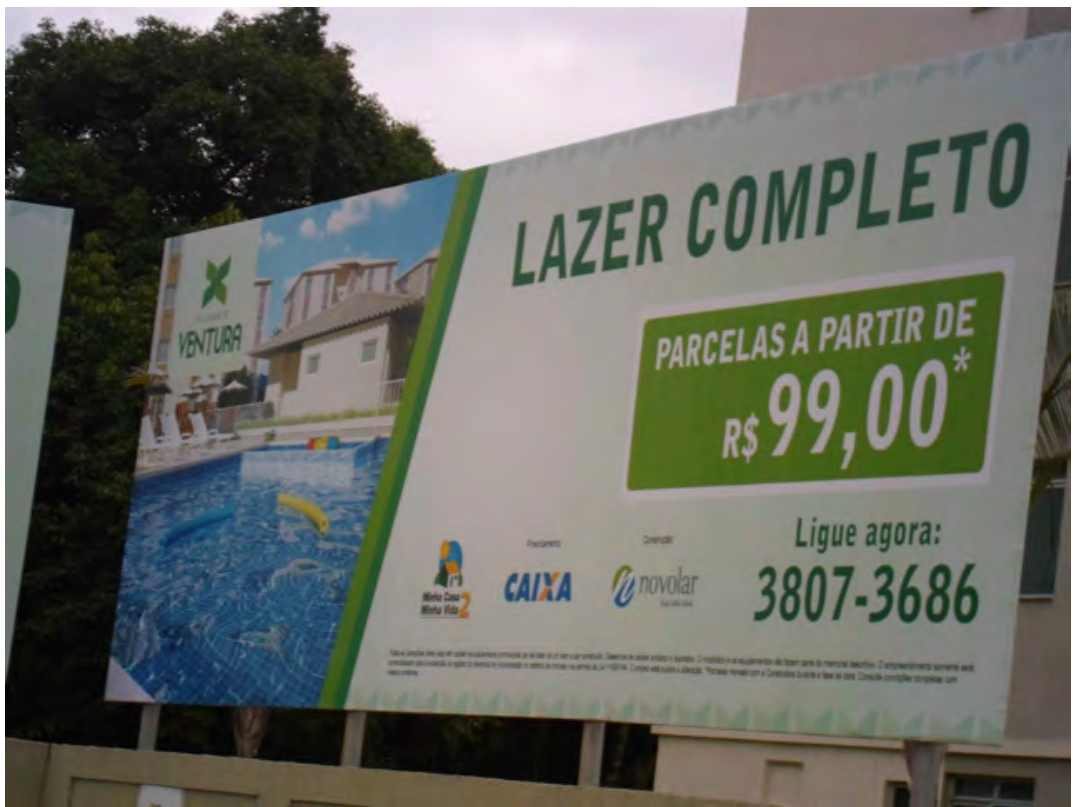

Autoria: Vânia Silva, 2015. Empreendimento com recurso do PMCMV para famílias que ganham entre 3 e 6SM. Uma apreensão do conceito de moradia condominial com lazer e privacidade

\section{Foto 2 - O entorno do empreendimento Village Ventura - Santa Cruz-RJ}

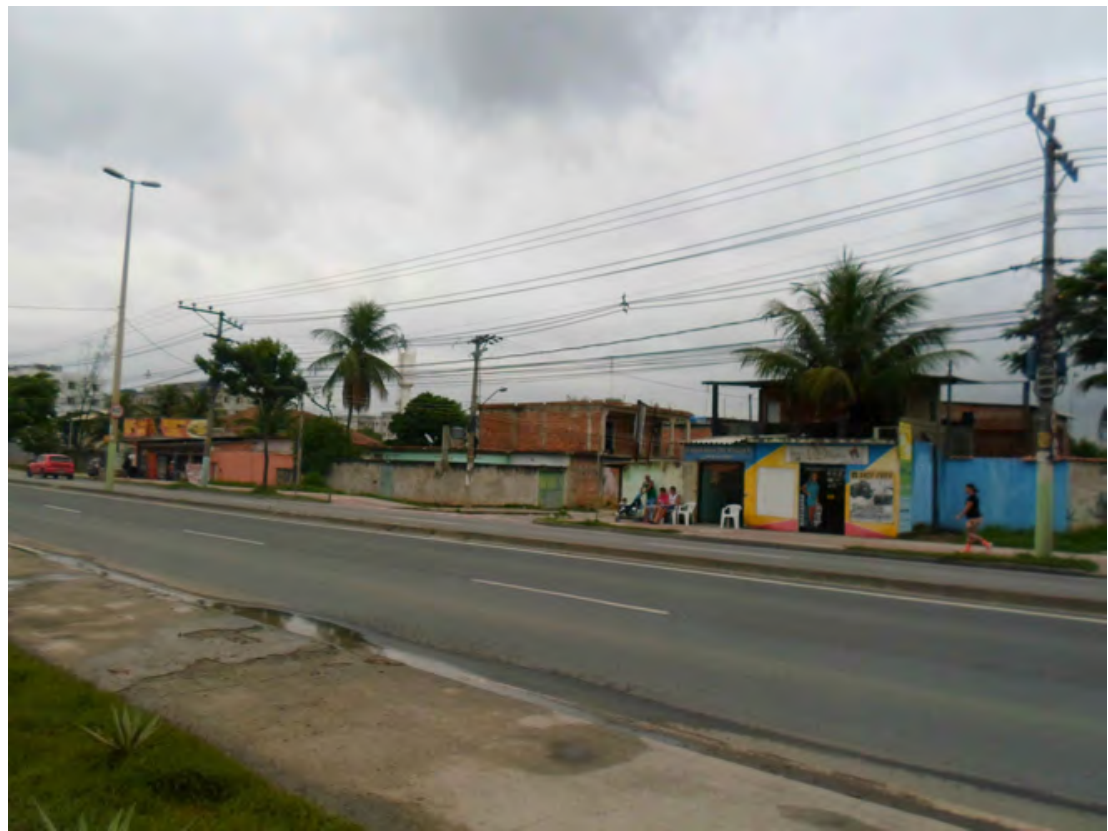


Antes de prosseguirmos, reafirmamos que, no recorte temporal selecionado para análise, no contexto nacional e, particularmente, na cidade do Rio de Janeiro, percebemos que o principal intento da produção imobiliária era a ampliação do excedente frente à crise de acumulação capitalista expressa a partir de 2008. Como conteúdo, temos a maior inserção do capital em diversos tipos de empreendimentos imobiliários diferenciados nas parcelas do espaço urbano, todos com estratégias que visam a possibilidade de expansão dos ganhos, como, por exemplo, o uso intensivo do solo em condomínios verticais. Esses aspectos são trabalhados na próxima seção.

\section{Os novos contextos de produçáo imobiliária na cidade do Rio de Janeiro: a participação do bairro de Santa Cruz}

Como ponto de partida, tomamos a noção de reestruturação imobiliária desenvolvida por Pereira (2014), considerando a distribuição desigual do valor e dos grupos sociais no território sob a ação do capital, percebendo a influência do Estado, das empresas e do capital financeiro como agentes nos negócios imobiliários, de acordo com uma política de habitação que vem em resposta às necessidades do mercado e do capital disponível para investimento, não em resposta à demanda por moradias. Observamos, assim, os empreendimentos imobiliários tanto nas antigas periferias distantes como nas áreas urbanas centrais com conteúdos sociais que denotam uma fragmentação urbana por serem diferenciados, e uma segregação diante da ênfase em condomínios com a promessa de segurança que, na verdade, cria separaçóes intraurbanas.

O que foi observado durante o período de dez anos (2005-15) pode ser caracterizado como urbanismo empresarial, porque são os agentes privados dos negócios que indicam a direçáo do crescimento da cidade tendo o patrimônio urbano e imobiliário como fonte de rendimento. Os espaços da cidade são instrumentalizados via empreendimentos imobiliários, inclusive do PMCMV, que direcionam estímulos e investimentos para a produção condominial que serve, sobretudo, ao interesse do capital. Sendo assim, a política urbana, mesmo aquela que tem um cunho de política habitacional social, é desfavorável aos que realmente necessitam, pois suas intençôes não são na direção da justiça social. Desfavorável porque concentram-se, na maior parte, em áreas distantes dos principais centros comerciais e de serviços, de locais 
de emprego e trabalho, onerando o deslocamento do morador e implicando no seu desgaste físico.

A partir do que discutimos a respeito da produçáo imobiliária de Santa Cruz, cumpre apresentar a quantidade de empreendimentos em comparação à urbe carioca. Nos relatórios disponibilizados pela SMU de 2005 até agosto de 2015 sobre quantitativos de licenciamentos por áreas e por unidades na cidade do Rio de Janeiro, obtivemos dados por bairros na medida em que houve disponibilidade de acesso. Quando não foi possível, apresentamos por Área de Planejamento (AP). Em todo o município, o ano de 2005 foi marcante com um aumento de 32,0\% de licenças novas em relaçáo a 2004. Entre os fatores apontados para esse expressivo crescimento, temos a conjuntura macroeconômica nacional no período caracterizada pelo aumento médio da renda da população, melhores condiçôes de financiamento e queda das taxas de juros.

$\mathrm{Na}$ verdade, a referida conjuntura foi engendrada pelo Governo Federal garantindo fundos de financiamento tanto para os empreendimentos que seguissem suas diretrizes como para os compradores, fossem de imóveis, móveis, eletrodoméstico etc., uma condição promovida para manter e aumentar a circulação da economia. Houve ainda políticas de isenção fiscal para determinados produtos relacionados com o setor imobiliário, como máquinas e equipamentos, e a garantia de juros baixos para o financiamento para a compra da casa própria associado ao aumento do número de prestaçóes.

As medidas tomadas promoveram a expansão do emprego e a possibilidade de aquisição do imóvel próprio. Além do exposto, os relatórios citam outros fatores que estimularam o setor imobiliário, como, por exemplo, os investimentos públicos e privados para tornar a cidade do Rio de Janeiro atraente para sediar megaeventos; os programas habitacionais sociais - como o Programa de Assentamento Residencial (PAR) que foi substituído em 2009 pelo PMCMV.

A atuaçáo do Governo Federal nesse contexto tem sido por meio de legislaçóes e instituições de pacotes econômicos como o PAC (Programa de Aceleraçáo do Crescimento). Com a primeira versão lançada em 2007, tendo como enfoque investimentos em infraestrutura de habitação, saneamento e transporte. A intenção dessa iniciativa pública foi atrair investimentos privados nacionais e internacionais. $\mathrm{O}$ primeiro $\mathrm{PAC}$ orçou suas bases na ordem de 503 bilhôes de reais, enquanto o segundo PAC, que começou em 2010, previu um montante de 1,59 trilhôes de reais para investir em transporte, 
energia, saúde, áreas sociais e habitação. A origem dessas verbas é de empresas estatais e de economia mista, do orçamento da União, da seguridade social e da iniciativa privada.

Devemos entender esse contexto como estratégias político-econômicas com a finalidade de fazer frente à conjuntura que se esboçava na escala global. O problema de insustentabilidade do setor imobiliário estadunidense reverberou sobre o modelo de acumulação de capital pautado na especulação financeira, desencadeando o que ficou conhecido como crise de 2008. Diante disso, o governo brasileiro adotou medidas para ampliar o crédito, inclusive, o destinado à construção civil e para a compra de imóveis.

Nesse cenário, houve uma ampliação da financeirização da produção imobiliária via Sistema Financeiro de Habitação (SFH), institucionalizado desde a Lei n. ${ }^{\circ}$ 9514/97, que permite a possibilidade de associação entre o capital financeiro e o setor imobiliário. Com o objetivo de ampliar a formaçáo de excedentes, as estratégias das empresas do setor imobiliário que atuam na cidade do Rio de Janeiro têm sido a de buscar terrenos amplos com metragem igual ou maior que $10.000 \mathrm{~m}$. Em determinados casos, esses terrenos têm como atrativo estarem localizados próximos a grandes eixos de transporte e com ligaçáo à região oceânica. Também há busca por terrenos grandes e a baixo custo em áreas deprimidas economicamente e pouco valorizadas, como é o caso do bairro de Santa Cruz, na Zona Oeste Carioca, que tem se tornado atrativo diante de investimentos de infraestrutura, como o Arco Metropolitano do Rio de Janeiro. Além desse, a retórica é de que, agora, aquela área está a dez minutos da Barra da Tijuca pelo Túnel da Grota Funda.

A partir de dados disponíveis quanto a licenças concedidas, somando-se as destinadas a usos residenciais, as não residenciais e as de usos mistos pela Secretaria Municipal de Urbanismo do Rio de Janeiro, tentamos realizar algumas análises para perceber o bairro de Santa Cruz no que diz respeito ao setor imobiliário com destaque para as novas construçóes. Fizemos algumas análises por ano, de acordo com a disponibilidade de informaçóes organizadas por Área de Planejamento (AP), Região Administrativa (RA) e bairros. O intento é de perceber como ocorreu a dinâmica de construçóes imobiliária na cidade do Rio de Janeiro procurando alguns dos aspectos mais relevantes e detalhados a respeito da AP5 por RAs e bairros, por conter o nosso recorte espacial de análise. 
O quadro 1, construído a partir da nossas análises dos relatórios, apresenta primeiramente as APs da cidade do Rio de Janeiro. A AP 5 é composta pelas RAs de Bangu, Campo Grande, Santa Cruz, Guaratiba e Realengo, com um total de 21 bairros $^{66}$ sendo que três deles, Campo Grande, Santa Cruz e Guaratiba, são os maiores em extensão. Como podemos observar, há aumentos de licenças nos anos de 2007, 2010 e 2014, de modo que apresenta-se como área de expansão do setor imobiliário propiciado, principalmente, pelos recentes investimentos em infraestrutura de transporte, como o BRT TransOeste e o Túnel da Grota Funda.

Quadro 1 - Número de licenças concedidas de 2005 - 2015 (até setembro) por AP na cidade do Rio de Janeiro

\begin{tabular}{c|c|c|c|c|c|c|c|c|c|c|c}
\hline AP & 2005 & 2006 & 2007 & 2008 & 2009 & 2010 & 2011 & 2012 & 2013 & 2014 & 2015 \\
\hline Total & 3680 & 3875 & 8760 & 3850 & 4209 & 3326 & 3200 & 3201 & 2854 & 2677 & 1436 \\
\hline AP 1 & 125 & 120 & 132 & 128 & 33 & 32 & 100 & 80 & 82 & 39 & 33 \\
\hline AP 2 & 451 & 555 & 783 & 400 & 75 & 108 & 148 & 84 & 93 & 106 & 62 \\
\hline AP 3 & 1379 & 1352 & 737 & 1384 & 726 & 705 & 616 & 661 & 564 & 626 & 347 \\
\hline AP 4 & 1071 & 1145 & 5378 & 1168 & 1003 & 923 & 1475 & 1534 & 1229 & 1018 & 435 \\
\hline AP 5 & 654 & 703 & 1024 & 770 & 2350 & 1557 & 861 & 842 & 886 & 1324 & 561 \\
\hline
\end{tabular}

Fonte: Secretaria Municipal de Urbanismo do Rio de Janeiro.

A título de comparaçáo, destacamos os bairros da AP5 que têm apresentado crescentes números de licenciamentos. Se tomarmos aleatoriamente o número acima de 100 licenças perceberemos alguns destaques nessa AP (quadro 2). Primeiramente, o bairro de Campo Grande desponta com número de licenças acima de 100 em todos os anos de 2005 até 2015, com notoriedade especial para o ano de 2009 com 1.089 licenças.

Logo a seguir, temos Santa Cruz que nos anos de 2007, 2009, 2010 e 2013 apresenta quantitativos de licenças superiores a 200 (respectivamente, 498, 402, 324, 202). Devemos compreender essa situação, dentro do

${ }^{6}$ Composição da AP 5 - RA XVII Bangu - Bangu, Gericinó, Padre Miguel, Senador Camará; RA XVIII Campo Grande - Campo Grande, Cosmos, Inhoaíba, Senador Vasconcelos; RA XIX Santa Cruz - Paciência, Santa Cruz, Sepetiba; RA XXVI Guaratiba - Barra de Guaratiba, Guaratiba, Pedra de Guaratiba; RA XXXIII Realengo - Campo dos Afonsos, Deodoro, Jardim Sulacap, Magalhães Bastos, Realengo, Vila Militar. 
PMCMV. Em seguida, percebemos o auge de licenças no ano de 2009 no bairro de Jardim Sulacap, que deve ser entendido no bojo de um evento internacional, os Jogos Mundiais Militares que aconteceu na cidade do Rio de Janeiro no mês de julho de 2011. E por fim, o aumento de licenciamentos no bairro de Guaratiba também no ano de 2009.

Quadro 2 - Licenças na AP 5 por RA e bairros nos anos de 2005 - 2015 (até o mês de setembro)

\begin{tabular}{|c|c|c|c|c|c|c|c|c|c|c|c|}
\hline RA e bairros & 2005 & 2006 & 2007 & 2008 & 2009 & 2010 & 2011 & 2012 & 2013 & 2014 & 2015 \\
\hline XVII Bangu & 145 & 162 & 29 & 183 & 260 & 97 & 90 & 73 & 106 & 205 & 58 \\
\hline Bangu & 105 & 104 & 23 & 30 & 90 & 82 & 66 & 48 & 74 & 152 & 41 \\
\hline \multicolumn{12}{|l|}{ Gericinó } \\
\hline Padre Miguel & 29 & 35 & 6 & 36 & 20 & 10 & 15 & 14 & 25 & 40 & 12 \\
\hline Senador Camará & 11 & 23 & & 17 & 150 & 5 & 9 & 11 & 7 & 13 & 5 \\
\hline $\begin{array}{l}\text { XVIII Campo } \\
\text { Grande }\end{array}$ & 344 & 319 & 489 & 373 & 1175 & 935 & 528 & 566 & 401 & 986 & 334 \\
\hline Campo Grande & 307 & 276 & 112 & 327 & 1089 & 728 & 469 & 522 & 331 & 785 & 250 \\
\hline Cosmos & 17 & 20 & 376 & 10 & 61 & 181 & 47 & 26 & 39 & 76 & 42 \\
\hline Inhoaíba & 6 & 10 & & 4 & 11 & 7 & 4 & 2 & 18 & 21 & \\
\hline Santíssimo & 9 & 5 & 1 & 14 & 9 & 16 & 6 & 7 & 7 & 94 & 35 \\
\hline $\begin{array}{l}\text { Senador Vascon- } \\
\text { celos }\end{array}$ & 5 & 8 & & 18 & 5 & 3 & 2 & 9 & 6 & 10 & 7 \\
\hline XIX Santa Cruz & 37 & 35 & 498 & 33 & 656 & 415 & 90 & 54 & 230 & 138 & 64 \\
\hline Paciência & 10 & 9 & & 10 & 254 & 91 & 17 & 16 & 26 & 39 & 11 \\
\hline Santa Cruz & 27 & 26 & 498 & 21 & 402 & 324 & 72 & 38 & 202 & 97 & 50 \\
\hline Sepetiba & & & & 2 & & & 1 & & 2 & 2 & 3 \\
\hline XXVI Guaratiba & 29 & 63 & & 47 & 147 & 52 & 77 & 80 & 65 & 2 & 36 \\
\hline $\begin{array}{l}\text { Barra de Gua- } \\
\text { ratiba }\end{array}$ & & & & 1 & & & 1 & & & & \\
\hline Guaratiba & 21 & 54 & & 42 & 124 & 43 & 59 & 67 & 60 & 2 & 29 \\
\hline $\begin{array}{l}\text { Pedra de Gua- } \\
\text { ratiba }\end{array}$ & 8 & 9 & & 4 & 23 & 9 & 17 & 13 & 5 & & 7 \\
\hline XXXIII Realengo & 99 & 124 & 8 & 134 & 112 & 58 & 76 & 69 & 84 & 201 & 69 \\
\hline $\begin{array}{l}\text { Campo dos } \\
\text { Afonsos }\end{array}$ & 1 & 2 & & & & 3 & & & & 6 & \\
\hline
\end{tabular}




\begin{tabular}{l|c|c|c|c|c|c|c|c|c|c|c}
\hline Deodoro & & 1 & & 2 & 1 & & 18 & & 13 & 8 & \\
\hline Jardim Sulacap & 27 & 28 & 3 & 36 & 405 & 9 & 8 & 17 & 10 & 19 & 13 \\
\hline $\begin{array}{l}\text { Magalhães } \\
\text { Bastos }\end{array}$ & 12 & 14 & & 12 & 26 & 6 & 50 & 4 & 60 & 19 & 8 \\
\hline Realengo & 57 & 75 & 5 & 84 & 73 & 39 & & 45 & 313 & 130 & 48 \\
\hline Vila Militar & 2 & 4 & & & 17 & 1 & & 3 & 1 & 19 & \\
\hline Total & 654 & 703 & 1024 & 770 & 2350 & 1557 & 861 & 842 & 886 & 1324 & 561 \\
\hline
\end{tabular}

Fonte: Secretaria Municipal de Urbanismo do Rio de Janeiro.

Para ressaltar o nosso período de análise (2005-15) que tem como contexto particular a reprodução do capital no urbano via setor imobiliário em conjunção com o financeiro em volume inédito, cabe tomarmos algumas das informaçôes do relatório da SMU para 2009 no qual realiza comparação com anos anteriores. Mencionando a década de 1980, podemos destacar que houve uma redução abrupta na área licenciada em 1984, com 2,3 milhôes de licenciamentos, em comparação com 1983 que teve 5,4 milhôes de $\mathrm{m}^{2}$. Essa situação é explicada pela extinção do BNH no contexto do esgotamento do modelo de desenvolvimento econômico adotado no Brasil entre os anos de 1960-80. A partir de 2005, a situação se reverte e o licenciamento passa a atingir um patamar de 3 milhóes $\mathrm{de}^{2}$ de forma consistente e com forte tendência de elevação. Como especificidade desse momento, podemos salientar a abertura de um novo mercado constituído pelos segmentos sociais de famílias que ganham até 10 salários mínimos, beneficiadas diretamente por políticas habitacionais do PMCMV, possibilitando a essa camada da populaçáo acesso ao mercado habitacional formal. Assim, em 2009 temos um volume de licenças no mesmo patamar do início dos anos 1980, com mais de 5 milhóes de $\mathrm{m}^{2}$ licenciados. Segundo o referido relatório, sete bairros concentraram $51,0 \%$ do total da área total licenciada, sendo que, cinco deles são da Zona Oeste carioca e três da AP 5, Campo Grande, Santa Cruz e Senador Camará, como pode ser visto no gráfico 1. Destaque para o bairro de Santa Cruz na quarta posição desse ranqueamento no gráfico 1 .

Em seguida, é possível perceber, a partir do gráfico 2, o total de unidades residenciais licenciadas em 2009. Campo Grande e Santa Cruz se destacam, representando cerca de 35,0\% do total dessas unidades. Destaque para Santa Cruz em segundo lugar na lista de participaçôes. As análises da 
SMU para 2010 continuam acusando o aumento da produção imobiliária na cidade do Rio de Janeiro, com um total de 7,0\% em relação ao ano anterior, com destaque para as APs 3, 4, 5 em números absolutos e aumento da participação relativa das AP3 e 5 em comparação às demais.

Para os gráficos do ano de 2010 referentes a áreas e a unidades licenciadas, podemos observar que o quadro de 2009 se repete. Observamos no gráfico 3, referente a unidades licenciadas, o bairro de Santa Cruz mais uma vez em segundo lugar no que diz respeito à área total licenciada e em segundo quanto a unidades totais licenciadas.

Em 2011, os relatórios apontam para um aumento de 8,2\% nos licenciamentos para a cidade do Rio de Janeiro. O bairro de Santa Cruz perde sua posição em 2010, caindo da segunda para a sexta no que diz respeito ao número de unidades licenciadas, como pode ser visto no gráfico 4 .

Gráfico 1 - Área total licenciada nos bairros com as maiores participações

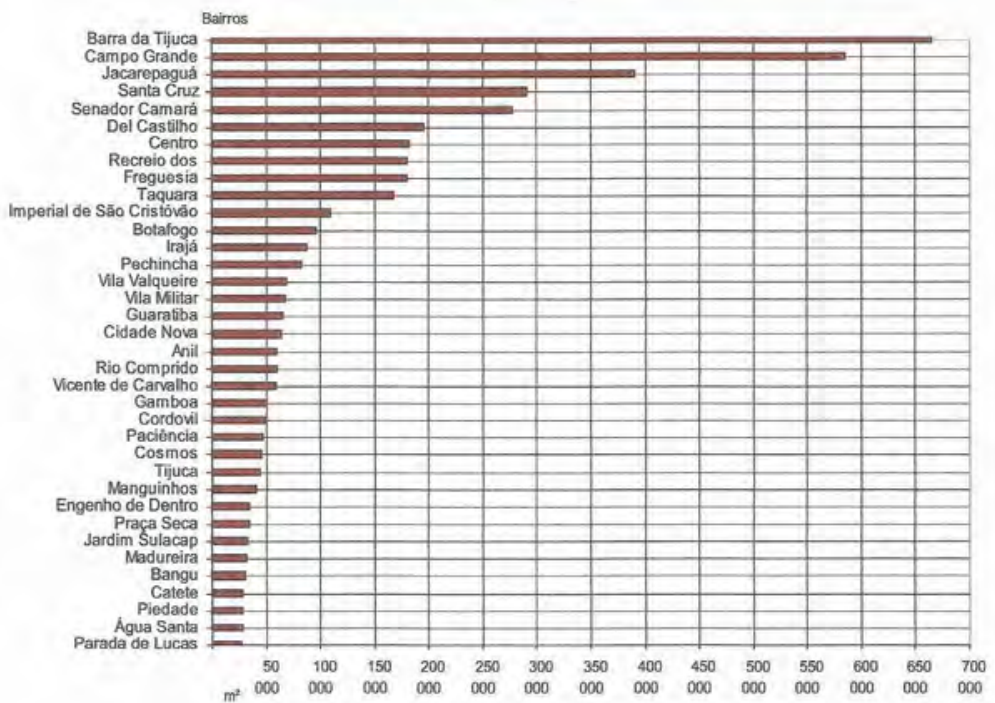

Fonte: Secretaria Municipal de Urbanismo do Rio de Janeiro. 
Gráfico 2 - No de unidades residenciais licenciadas nos bairros com as maiores

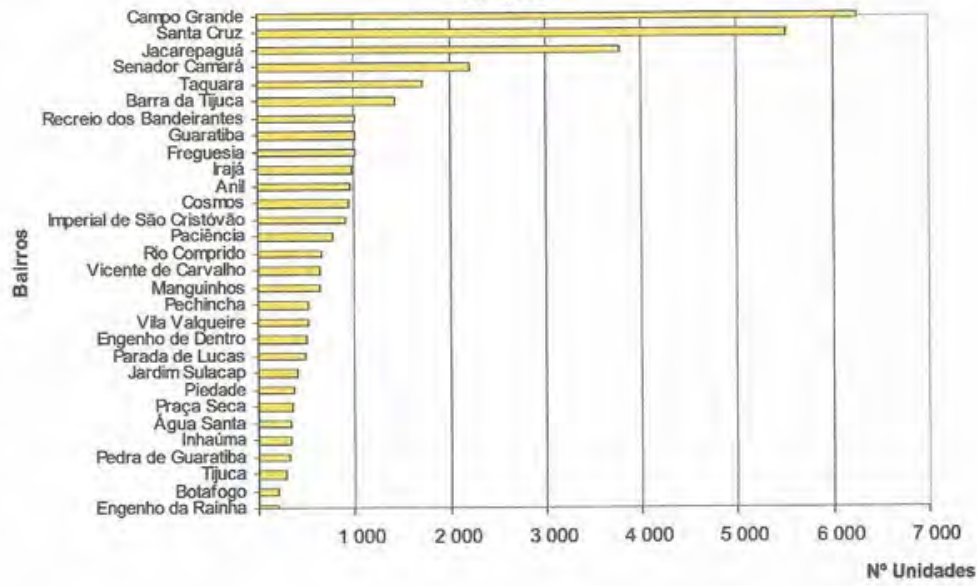

Fonte: Secretaria Municipal de Urbanismo do Rio de Janeiro.

Gráfico 3 - Total de unidades licenciada nos bairros com as maiores participaçóes - 2010

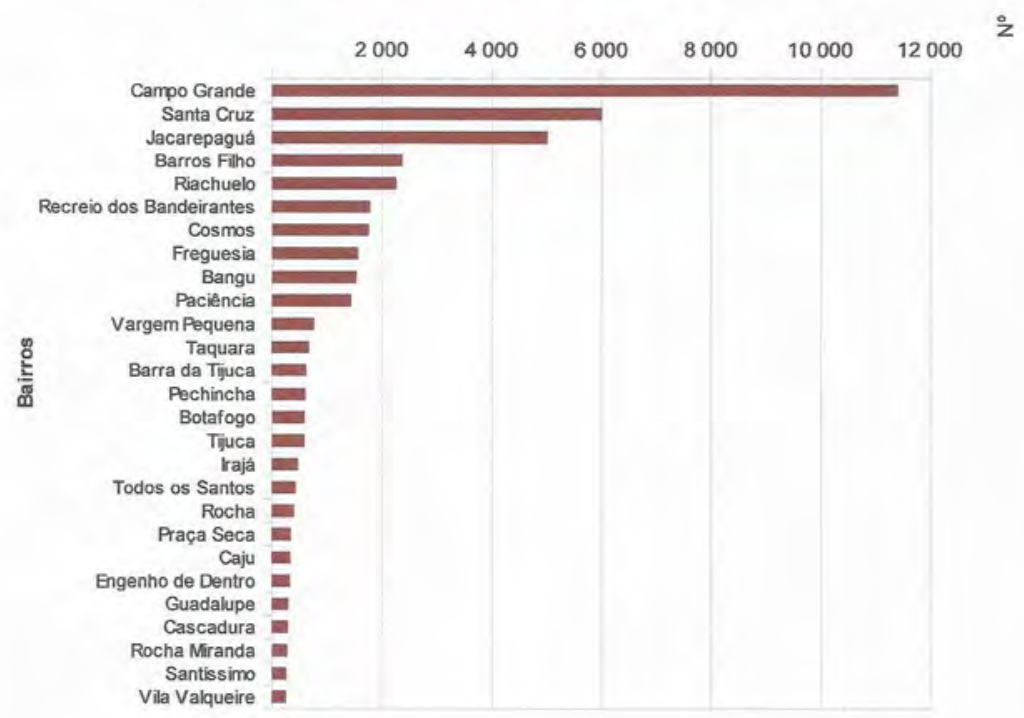

Fonte: Secretaria Municipal de Urbanismo do Rio de Janeiro. 
Gráfico 4 - No de unidades licenciadas - total, residencial, não-residencial, por bairro, com no igual ou acima de 150 unidades licenciadas - 2011

Número de Unidades Licenciadas Total, Residenclal e Năo Residencial, por Bairro, com número de unidades licenciadas igual ou maior que $150-2011$

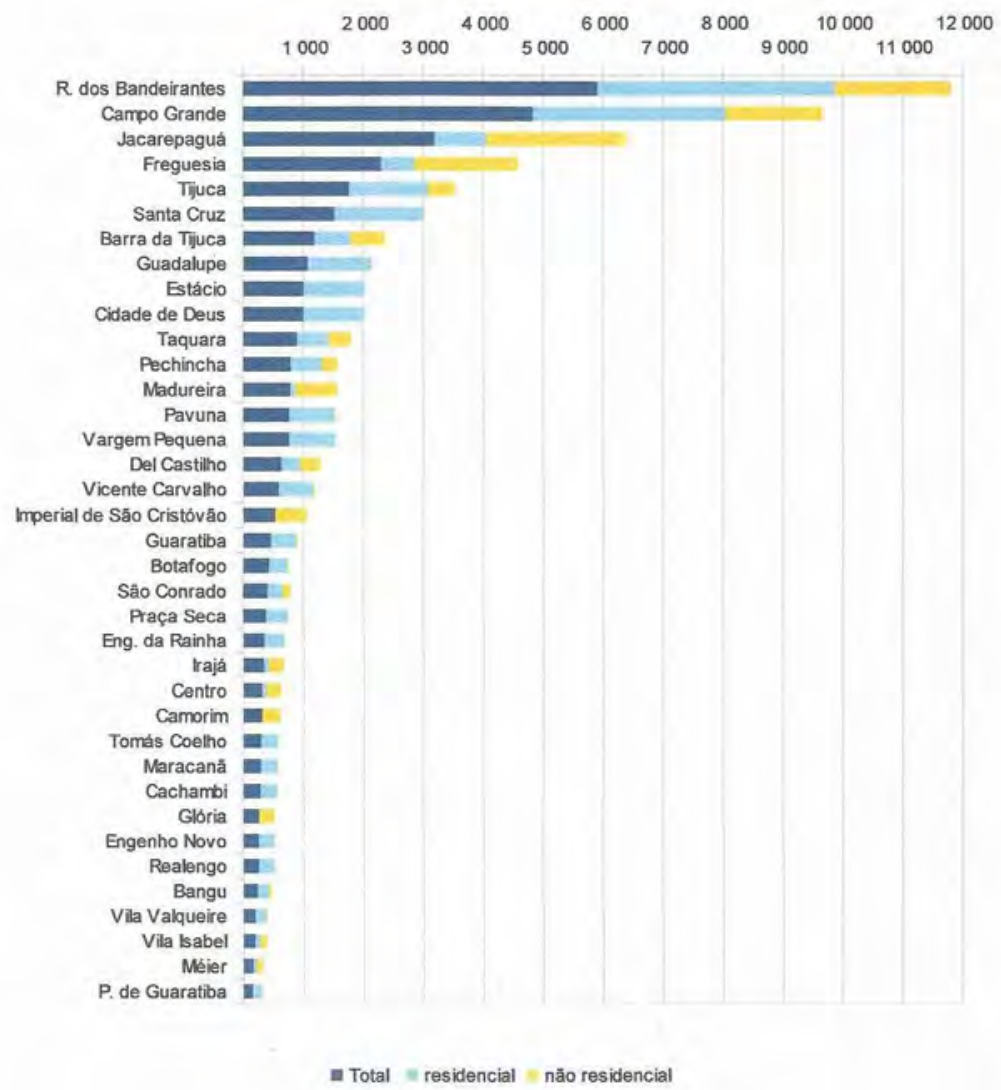

Fonte: Secretaria Municipal de Urbanismo do Rio de Janeiro.

Para 2012, temos uma queda de $-2,0 \%$ no total da área licenciada em relação a 2011, apontando para uma estabilidade no setor ou esgotamento do modelo de produção imobiliária adotado. Mesmo assim, as cifras totais continuam altas, visto que em 2012 foram licenciados um total aproximado de 5,2 milhóes de $\mathrm{m}^{2}$ contra 5,3 milhóes em 2011. O gráfico 5 registra uma queda vertiginosa no licenciamento da AP5. Essa situaçáo nos acusa que o setor começa a dar sinais de esgotamento no que diz respeito à produção 
visando a camada da população menos abastada, considerando que o grande volume apresentado nos bairros da AP5, principalmente em Campo Grande e em Santa Cruz, estão relacionados ao PMCMV.

Gráfico 5 - Área total licenciada, conforme uso, por Área de Planejamento - 2012

Área Total Licenciada, conforme o Uso, por Área de Planejamento - 2012

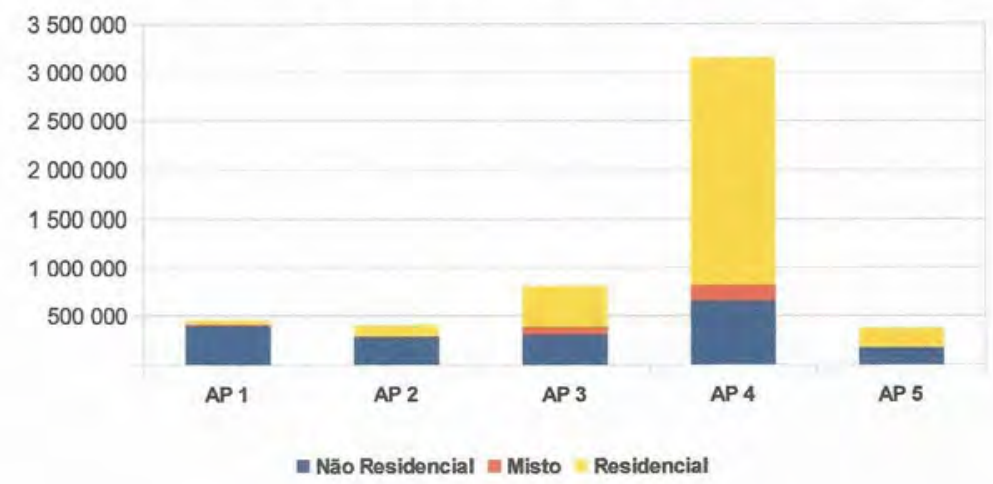

Fonte: Secretaria Municipal de Urbanismo.

Embora apresente, no geral, um quadro ainda positivo, o resultado do licenciamento no ano de 2013, segundo os relatórios da SMU, também registra sinais de desaquecimento e retraçáo em todo o setor imobiliário segundo a Câmara brasileira da indústria da Construção Civil. Só na AP5, a queda foi de 19,3\% nas edificaçóes no primeiro trimestre em relação ao mesmo período do ano anterior. $\mathrm{O}$ ano de 2015 continua o quadro apresentado no ano anterior com um aumento de 4,0\% no mês de agosto em relação ao mesmo mês em 2014. No entanto, os números acumulados até agosto de 2015 de áreas licenciadas no período caíram em 24,9\%.

Em síntese, o que queremos destacar é que a área que compreende a AP5 vem se caracterizando como sendo de interesse para a expansão imobiliária. De 2005 até 2015 a AP5 se apresentou como mais uma área de vultosos números de empreendimentos. Isso ocorreu diante dos investimentos estatais em infraestrutura viária e de transporte, evidenciando essa área para o interesse do capital. 
Os dados informados acima apresentam o bairro de Santa Cruz estando sucessivamente entre os bairros que mais lograram licenciamento nos anos analisados. Porém, temos que perceber qual é o conteúdo social dessa produção capitalista de moradias no referido bairro.

Em conformidade com toda essa discussão, passamos a analisar de maneira mais acurada a produção imobiliária para a população de menor renda, que no nível municipal está sob a Lei n. ${ }^{\circ}$ 40/1999 relativa a empreendimentos de interesse social de baixa renda incluído em programas de política social habitacional de outras esferas do governo. O que temos observado na cidade do Rio de Janeiro é a alocação de tais empreendimentos em áreas que não atendem todas as especificaçóes normatizadas pela lei, principalmente no que diz respeito ao transporte público e aos equipamentos de saúde e de educação. Além disso, essa legislação prevê a construção de, no máximo, 500 unidades por empreendimentos de quatro andares. Mas, para que as empresas possam ampliar seus excedentes, muitas têm burlado a legislação, construindo mais de 1000 unidades divididas em empreendimentos diferentes para o mesmo terreno.

Segundo Cardoso (2011), há duas possibilidades de formação de excedentes pelas empresas que não são excludentes. Uma delas é a redução do custo de construção, a outra é a redução do preço da terra, ou seja, dois tipos de lucratividade de naturezas diferentes. A redução do preço da terra se refere ao lucro imobiliário que é maximizado com a capacidade das empresas desenvolverem estratégias de redução do valor pago ao proprietário. Nesse sentido, a ampliação da escala dos empreendimentos implica na busca por glebas mais amplas, reforçando a tendência de expansão para a Zona Oeste, local com maior disponibilidade desses terrenos.

Observamos que o PMCMV transcende a dimensão social da questão habitacional e se insere na dimensão político-econômica, tornando-se elemento chave para a dinamizaçáo da economia. $\mathrm{O}$ modelo adotado coloca a iniciativa privada como principal agente promotor da política que decide onde o empreendimento será construído, a faixa de renda beneficiada e as características dos imóveis, cabendo à administração municipal realizar levantamento da demanda e sortear os contemplados para adesão ao programa para as unidades que realmente têm a função de habitação social, são destinadas para famílias que recebem até 3 SM.

Exemplificando com a adesão dos consumidores, não se pode negar que o programa tem permitido que famílias que ganham menos de três salários mí- 
nimos possam obter seus imóveis. Ou seja, é uma parcela da população que alcançou a possibilidade da propriedade privada por meio do mercado formal. Embora saibamos que alguns dos proprietários de unidades MCMV podem ter sido forçados a aderir ao empreendimento em virtude de remoçóes de áreas da cidade que estão passando por processo de requalificação, como é o exemplo da área portuária do Rio de Janeiro, muitos aderem voluntariamente para escapar das áreas de risco ou com alto índice de violência, além daquelas que estão "interessadas em obter garantia legal definitiva da posse do imóvel, ou [...] seduzidas pelo desejo de consumir um 'produto' imobiliário diferenciado, materializado pela tipologia condomínio-fechado amplamente adotada pelas incorporadoras que produzem para o programa" (Cardoso e Jaenisch, 2014, s/n).

Como já afirmamos, o aumento da escala de construção significa realizar vários empreendimentos com licenças diferentes no mesmo terreno. $\mathrm{Na}$ foto 3 , temos três licenciamentos em um só terreno, o Parque Recanto Verde, o Recanto da Serra e o Recanto da Colina, todos construídos pela MRV Engenharia com cerca de 500 unidades cada, dotados de áreas de lazer e segurança.

Foto 3 - Três empreendimentos MCMV pela MRV na Estrada Padre Guilherme de Decaminada - Santa Cruz-RJ

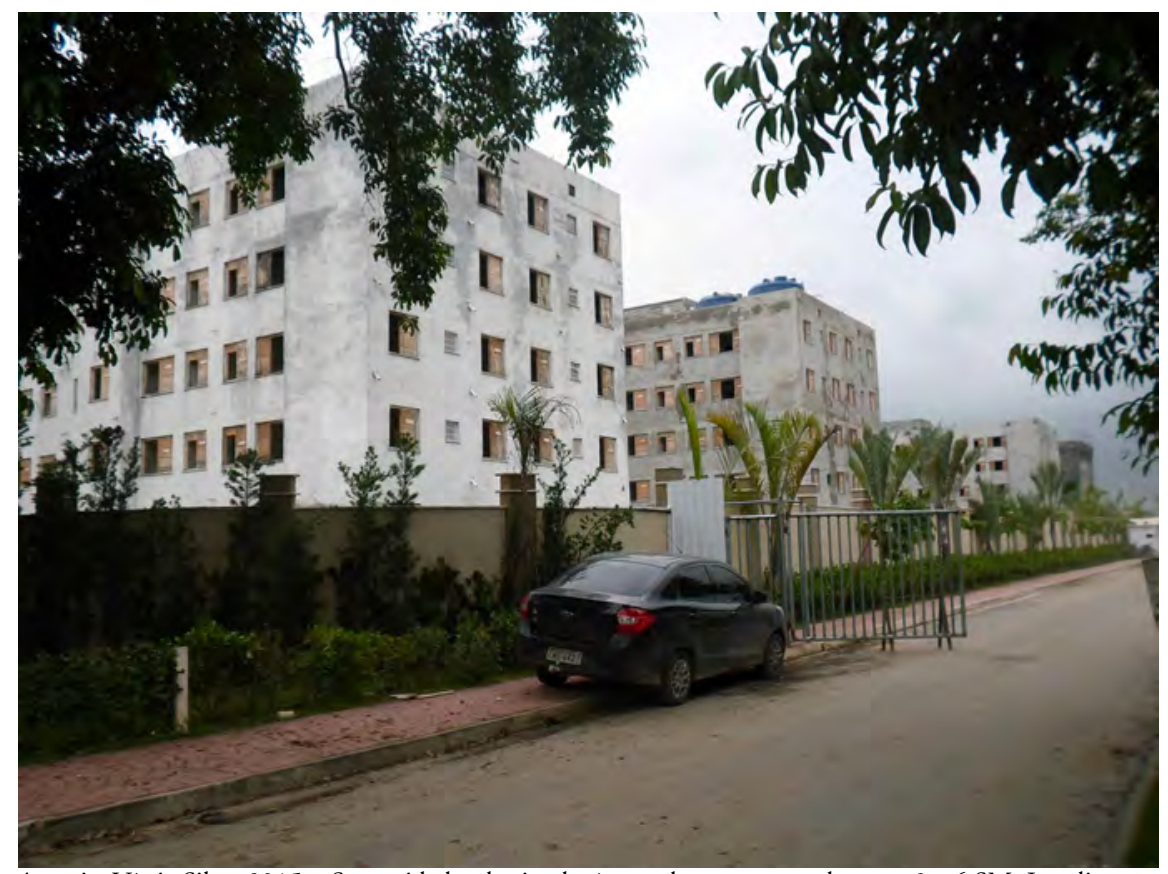

Autoria: Vânia Silva, 2015 - São unidades destinadas à população com renda entre 3 e 6 SM. Localiza-se perto da Av. Brasil e oferece total infraestrutura de lazer e segurança. 
Posto isto, podemos destacar a configuração das construçóes do PMCMV por faixa de rendimento. Do total de unidades contratadas pelo município do Rio de Janeiro, 48,2\% são para a faixa 1 (0 a 3 salários mínimos), $16,3 \%$ para a faixa 2 (3 a 6 salários mínimos) e $35,4 \%$ para a faixa 3 (6 a 10 salários mínimos). Deste total, 48,3\% estáo localizadas na Zona Oeste Carioca, nos bairros de Campo Grande, Santa Cruz, Cosmos, Paciência, Senador Camará, Guaratiba, Inhoaíba, Santíssimo, Realengo, Bangu, Pedra de Guaratiba, Jardim Sulacap e Senador Vasconcelos.

É possível ressaltar que $58,5 \%$ das unidades dessa área foram destinadas a população que se enquadra na faixa 1 e $41,5 \%$ para as faixas 2 e 3 . Cabe ressaltar, ainda, que segundo o relatório da SMU em abril de 2010, cerca de 93,3\% do total das unidades habitacionais em análise ou licenciadas para o PMCMV em 2010 estão Na AP5 (figura 2).

Figura 2 - Unidades de habitação do PMCMV por bairro no município do Rio de Janeiro

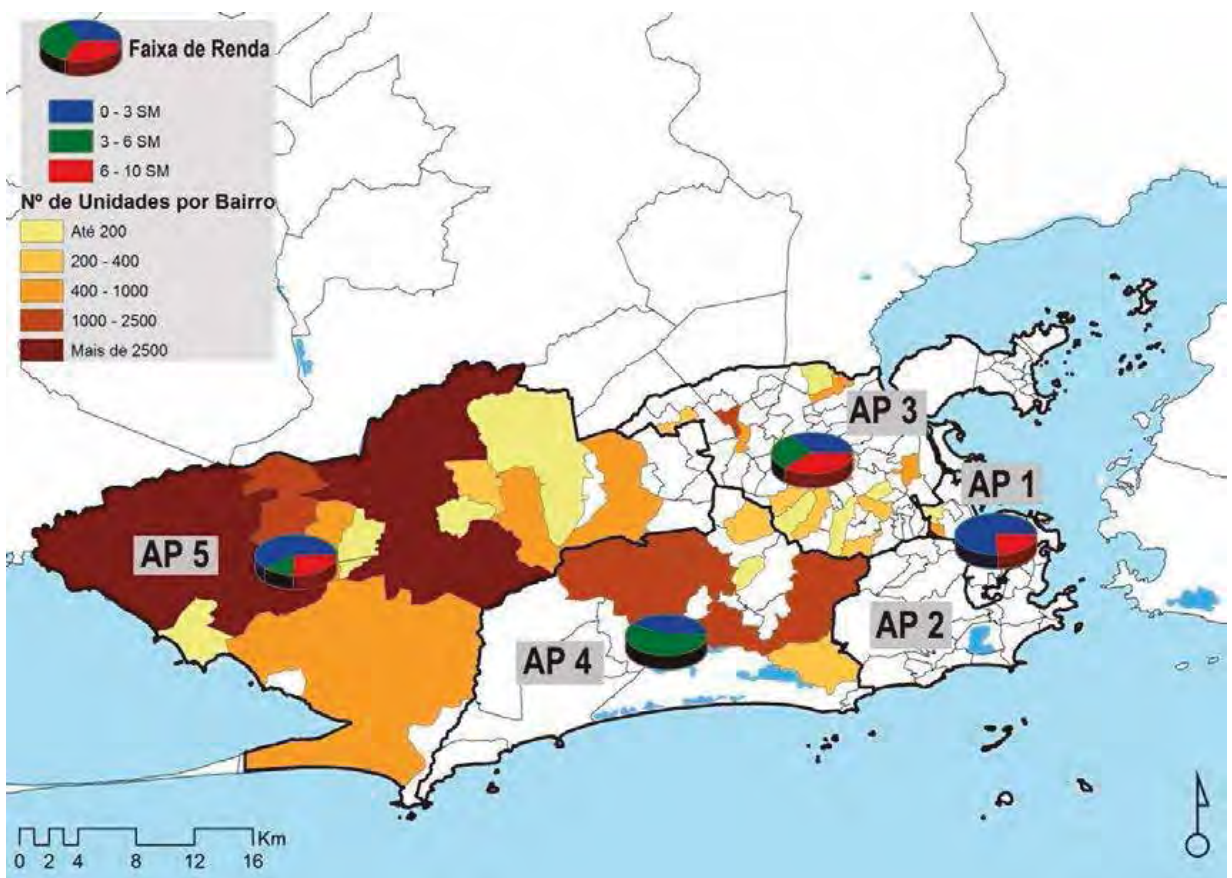

Fonte: Cardoso et al., 2013. 
Esses empreendimentos da MRV têm como atrativo o fato de propor apartamentos de dois quartos em Santa Cruz, com ou sem suíte, em condomínio fechado, com área de lazer completa, Saláo de Festas, Playground, Espaço Fitness, Quadra Gramada, Espaço Gourmet, Piscinas Adulto e Infantil, Próximo ao Supermercado Extra, Shopping Pátio Mix Itaguaí, Hospital Pedro II, Estação BRT Santa Cruz e Estação de Trem Santa Cruz, tendo como vias de acesso a Av. Brasil, a BR-101, a Av. Joáo XXIII e a rodovia Rio-Santos.

Cabe ainda registrar que, do total de construçôes do PMCMV para os anos de 2009 até 2015, 54.976 unidades foram para o Rio de Janeiro. Destas, $42.980(78,2 \%)$ foram para a AP5. É importante enfatizar que, desses totais, o bairro de Santa Cruz participa com 16.064, representando 29,2\% em relação à cidade do Rio de Janeiro e 37,4\% em relaçáo à AP5. No bairro, 12.697 unidades são destinadas à faixa de renda mais baixa. Isso significa $23,0 \%$ do total da cidade, $29,5 \%$ em relação ao total de AP5, 36,1\% em relação ao total de construçôes para a faixa 1 na cidade do Rio de Janeiro que é de 35.121 unidades.

Nota-se, portanto, a preponderância do bairro de Santa Cruz no que diz respeito à construção de unidades MCMV, sobretudo, na faixa de renda de 0 a 3 salários mínimos. Como já abordamos anteriormente, isso não significa apenas essa é uma estratégia para deslocar a populaçáo menos abastada para longe das áreas mais dinâmicas economicamente do Rio de Janeiro. Antes disso, diante da política implementada na qual o empresariado se serve de condiçóes propícias para auferir grandes ganhos em todos os nichos de mercado, a populaçáo de menor renda tornou-se mais um desses nichos. A estratégia que explica a maior concentração dos empreendimentos MCMV em Santa Cruz e em outros bairros de AP5 diz respeito ao valor máximo da unidade habitacional pré-determinado pela Caixa Econômica Federal, que era de $\mathrm{R} \$ 190.000,00$ para a Regiáo Metropolitana do Rio de Janeiro. Assim, as incorporadoras apostam no volume produzido para aumentar os ganhos em terrenos mais amplos. Sabemos que os terrenos que comportam essa prática não estáo disponíveis em todo o tecido urbano carioca. Devido à extensão de Santa Cruz e de seu histórico de ocupação, o bairro apresenta terrenos de acordo com essas especificaçóes tornando-se área propícia para esse tipo de construção em larga escala, fazendo com que o capital incorporador extraia lucros excedentes. 


\section{Consideraçóes finais}

$\mathrm{Na}$ escala intraurbana carioca, autores como Silva (1996) e Abreu (2006) analisaram o prolongamento do núcleo metropolitano pelos bairros da Barra da Tijuca e, mais tarde, do Recreio, denotando processos desencadeados nas décadas de 1980 e 1990 . A esse respeito, observamos o capital imobiliário buscando ampliar seus lucros com o empreendimento carregado de simbolismo para as classes média-alta e alta representado por condomínios fechados, afastados da Área Central adensada e com infraestrutura de lazer e segurança.

Na pesquisa, destacamos os empreendimentos imobiliários, principalmente os voltados para habitaçáo social do PMCMV no bairro de Santa Cruz. Assim, observamos em Silva (1996) o novo conceito de morar que foi lançado na década de 1980 para as camadas da população de classe média e média alta na direção da Zona Norte carioca e, principalmente para a Barra da Tijuca, com habitação em condomínios fechados com estruturas de lazer, segurança e áreas exclusivas. Trata-se da construção de um simbolismo que também passou a ser utilizado para a produção de habitação social. Entendemos assim, que o volume de empreendimentos em condomínios fechados do PMCMV promove a possibilidade de grandes ganhos pelo capital imobiliário formal por meio da produção intensiva por terreno para driblar a imposição do preço máximo do imóvel nesse tipo de produção imobiliária.

A partir do momento em que entendemos o espaço produzido de Santa Cruz, fizemos uma análise do referido recorte no contexto da cidade do Rio de Janeiro. Buscando analisar em quais aspectos o período mais recente se diferenciou dos anteriores no sentido político e econômico, de acordo com os dados disponíveis quanto a licenças concedidas, percebemos o bairro de Santa Cruz se destacando para as novas construçóes imobiliárias em relação ao restante da cidade do Rio de Janeiro. Compreendemos que os empreendimentos sociais de grande porte significam um artifício para reduzir os custos e ampliar os lucros, não simplesmente a alocação prioritária de pobres na periferia.

Como observamos, há a prática da empresa incorporadora procurar terrenos amplos e acessíveis que são mais comuns nas áreas afastadas e fracionar os lotes de terras em vários empreendimentos criando conjuntos contíguos.

Diante desse contexto, o que podemos observar em relação ao bairro de Santa Cruz é que, mesmo estando nos limites do núcleo metropolitano, devido à disponibilidade de terrenos amplos e acessíveis se apresenta como 
uma área propícia para a expansão urbana e frente de interesse para o capital imobiliário em determinado nicho, para a população de menor renda. Então, entendemos essa produçáo imobiliária no referido bairro com ênfase nos empreendimentos do PMCMV, antes de tudo, como uma forma de reprodução do capital via urbano que ocorre na direção oeste da urbe carioca se configurando como uma expansão urbana via setor imobiliário.

Devido aos conteúdos supracitados, a dinâmica imobiliária nesse recorte é diferente da expansão do período urbano-industrial e se insere no processo de metropolização porque é possível atrelá-lo à gama de empreendimentos e instalaçóes do setor produtivo e de infraestrutura, e ainda porque essa dinâmica se expressa na junção ente o setor financeiro e o imobiliário.

Devemos acrescentar que, na época do Programa, foi prevista a terceira fase do PMCMV com a meta de construir mais de três milhóes de unidades até 2018, tendo como mudanças para os novos contratos quatro faixas de renda, com a criação de mais uma para quem recebe entre $\mathrm{R} \$ 1.800,00$ e $\mathrm{R} \$$ $2.350,00$. As famílias que se encaixam nessa faixa contaráo com um subsídio de até R \$ 45 mil do Governo Federal e pagarão juros de 5,0\% ao mês. Ainda, as que ganham até $\mathrm{R} \$ 1.800,00$ terão isenção de $100,0 \%$ dos juros. E, as famílias com renda a partir de $\mathrm{R} \$ 2.350,00$ até $\mathrm{R} \$ 6.000,00$ terão aumento dos juros cobrados e pagarão percentuais entre 6,0\% e 8,0\% (Laporta, 2015).

Essa informação nos aponta a necessidade de continuar pesquisando a produção imobiliária em Santa Cruz, bem como nos demais que bairros que compóem a Zona Oeste Carioca ao norte do Maciço da Pedra Branca.

Como agenda para futuras pesquisas, podemos apontar nosso interesse pela AP5 e pelos bairros de Campo Grande e Santa Cruz. Tal fato se reafirma porque reconhecemos diferenças entre os mesmos. Nosso interesse é perceber o que os diferencia para o setor imobiliário.

A justificativa dessa indagação ocorre pela expansão imobiliária em Campo Grande para residentes de classe média destacado por Macedo (2002); Lago e Mammarella (2009); Miranda e Miller (2010); Cardoso e Lago (2015); Ribeiro e Ribeiro (2015).

Além disso, na presente pesquisa podemos observar, a partir dos dados e gráficos apresentados, a proeminência da produção imobiliária em Campo Grande se comparado aos demais bairros da AP 5. Se tomarmos a ideia de que a construção do túnel da Grota Funda e do BRT TransOeste abriu uma fronteira para a expansão imobiliária, como podemos entender a produção 
ainda tímida nos bairros de Guaratiba, Pedra de Guaratiba, Barra de Guaratiba e Sepetiba?

Podemos afirmar, segundo as ideias expressas por Barbosa (2017, pp. 432 e 434) que,

a política de produção de novas residências não foi e jamais será suficiente para resolver a questáo da moradia urbana sem a devida incorporaçáo do controle público da propriedade privada. [...] O construir e o habitar significam inventar possibilidades de existência diante da ordem urbana perversamente desigual.

Por outro lado, passados mais de quatro anos, o referido Programa encontra-se em atraso em suas operaçóes (O Globo, 2019), comprometendo os sujeitos sociais de classes de menor poder aquisitivo nas quais a moradia popular é um dos elementos mais significativos da luta social pelo espaço urbano, no qual o direito a moradia é uma das condiçóes de cidadania.

\section{Referências}

BARBOSA, Jorge Luiz. "O direito à morada". In: FERREIRA, Alvaro et al. O espaço e a metropolização: cotidiano e ação. Rio de Janeiro: Consequência Editora, 2017. pp.425-40. BRENNER, Neil. "Teses sobre a urbanização". In: emetropolis. n. 19, ano 5, dez. 2014. pp. 6-25.

CARDOSO, Adalto Lúcio. "Habitação de interesse social: política ou mercado? Reflexos sobre a construção do espaço metropolitano". XIV Encontro Nacional da Anpur. Rio de Janeiro, 2011.

e JAENISCH, Samuel Thomas. "Nova política, velhos desafios: problematizaçōes sobre a implementação do programa minha casa minha vida na Região Metropolitana do Rio de Janeiro". In: emetropolis. n. 18, ano 5, set. 2014. pp. 6-19.

e LAGO, Luciana Correa do. "Dinâmica Imobiliária: Estado e capital imobiliário". In: RIBEIRO, Luiz Cesar de Queiroz (Org.). Rio de Janeiro: transformaçôes na ordem urbana. 1. ed. Rio de Janeiro: Letra Capital; Observatório das metrópoles, 2015. pp. 320-53.

et al. Morando no limite: sobre padröes de localização e acessibilidade do Programa Minha Casa Minha Vida na Região Metropolitana do Rio de Janeiro. XV Encontro Nacional d Anpur. Rio de Janeiro, 2013.

FERREIRA, Álvaro. "Metropolização do Espaço, cotidiano e ação: uma contribuição teórico-

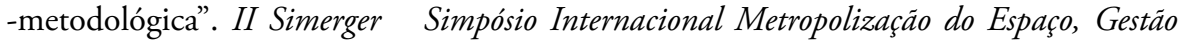
Territorial e Relaçōes Urbano-Rurais, 2014. Disponível em: http://simegerpucrio.wix.com/ simeger. Acesso em 12 mar. 2015. 
LAGO, Luciana Corrêa do e MAMARELLA, Rosetta. "Da hierarquia de classes à organização social do espaço intra-urbano: um olhar comparativo sobre grandes metrópoles brasileiras". In: $33^{\circ}$ Encontro Anual da Anpocs, Caxambu, 2009.

LAPORTA, Tais. "Entenda as novas regras do Programa Minha Casa Minha Vida”. G1 - Economia. Disponível em: http:/g1.globo.com/economia/noticia/2015/09/entenda-novas-regras-do-programa-minha-casa-minha-vida.html. Acesso em 20 nov. 2015.

LENCIONI, Sandra. "Concentração e centralização das atividades urbanas: uma perspectiva multiescalar. Reflexóes a partir do caso de São Paulo”. In: Revista de Geografía Norte Grande, n. 39. Santiago: Pontificia Universidad Católica de Chile, 2008. pp. 7-20.

. "Metropolização e a constituição da mega-região". In: II Simeger - Simpósio Internacional de Metropolização do Espaço, Gestão territorial e Relaçóes urbano-rurais. Metropolização do espaço: processos e dinâmicas. Disponível em: http://simegerpucrio.wix.com/simeger. http://simegerpucrio.wix.com/simeger. Acesso em 10 abr. 2015.

MACEDO, Andréia Pereira de. Produção Imobiliária e segregação na periferia do Rio de Janeiro: o bairro de Campo Grande. (Dissertação). Rio de Janeiro: UFRJ, 2002. 156p.

MIRANDA, Gisele dos Santos de e MÜLLER, Clarisse da Cunha. "As transformaçôes locais no "bairro" Rio da Prata, em Campo Grande , a partir da expansão de condomínios fechados: uma perspectiva multiescalar da dinâmica espacial da cidade do Rio de Janeiro - RJ". XVI Encontro Nacional de Geógrafos. Porto Alegre: Universidade Federal do Rio Grande do Sul, 2010. Disponível em file://C:/Users/Ruiz/Downloads /download(924).PDF.

PEREIRA, Paulo Cesar Xavier. "Dinâmica imobiliária e metropolização: a nova lógica do crescimento urbano em Sáo Paulo”. Scripta Nova-Revista electrónica de geografia y ciências sociales. v. IX, n. 194, ano 10, 1 ago. 2005.

. Reestruturação imobiliária e produção do espaço metropolitano. II Simerger - Simpósio Internacional Metropolização do Espaço, Gestão Territorial e Relaçôes Urbano-Rurais, 2014. Disponível em: http://simegerpucrio.wix.com/simeger. Consultado em: 12/03/2015.

O GLOBO. FGTS vai arcar com todo subsídio no Minha Casa. Economia, 12 mpv; 2019, p. 19.

RIBEIRO, Luiz Cesar Queiroz e RIBEIRO, Marcelo Gomes. "Segregação residencial: padróes e evolução”. In: RIBEIRO, Luiz Cesar de Queiroz (Org.). Rio de Janeiro: transformaçóes na ordem urbana. 1. ed. Rio de Janeiro: Letra Capital; Observatório das metrópoles, 2015. pp. 163-92.

SÁNCHEZ, Joan-Eugeni. "Barcelona: transformaciones em los sistemas productivos y expansión metropolitana”. In: MONCLÚS, Francisco Javier. La ciudad dispersa. Suburbanización y nuevas periferias. Barcelona: Centro de Cultura Contemporània de Barcelona. 1998. pp. 59-81.

SILVA, Carlos Alberto F. da. "A promoção imobiliária recente no município do Rio de Janeiro". Revista Território, n. 1, v. 1, 1996. pp. 43-57.

SMITH, Neil. "Gentrificação, a fronteira e a reestruturação do espaço urbano”. GEOUSP _ Espaço e Tempo, n. 21. São Paulo, 2007, pp. 15-31.

SILVA, Vânia Regina Jorge. O bairro de Santa Cruz-RJ no contexto da metropolização: escalas, dinâmicas e processos socioespaciais - 2005-2015. (Tese). Rio de Janeiro: UERJ. 2016. 